outweighed the disadvantages of a lower standard of living.

Setting up the Halle institute has so far cost the Max Planck Society DM9.8 million (US\$6 million). Half of this money is provided by the federal government and the other half by the eastern states. The funding is independent of Max Planck's 1992 DM1,400 million budget, split equally between regional governments in the west and the federal government. In some respects the Halle institute was added to the fold on the cheap. Salaries are only 60 per cent of those in the west, and it will be a few years before they will be equalized. Although pay is still better than under the DDR, the cost of living is rising rapidly in the east and the staff are keen for wage parity. Last week, Bonn announced that rents (which are state controlled in Germany) in eastern states are to be doubled by the end of the year. The second Max Planck institute planned in eastern Germany will be of a similar size to Halle. Three research groups, from Adlershof and Teltow near Berlin and from Freiberg in Saxony, will be brought together to work on interdisciplinary projects investigating the structure, dynamics and physical and chemical properties of colloidal systems. Its location will be decided this summer.

The society is also keen to safeguard two further areas of research excellence in the former DDR. In March it announced its intention to support two further institutes one in infection biology and the other in plant molecular physiology - as soon as money becomes available.

But when will that be? And will the west accept the increasingly high price of supporting the political ideals of those who wish to raise east German standards to their own? In the sudden political and economic uncertainty of Germany, these questions are difficult to answer.

Despite the special funds that have been set up to support research in the former DDR, it is clear that the government's persistent denial that the west must make sacrifices has lost credence. In fact, last week Research Minister Heinz Riesenhuber announced that 100 jobs would be lost in large research centres in the west so that money can be redirected "to bring the level of research in East Germany to levels in West Germany as quickly as possible." It was the government's first admission that there will be scientific losers as well as winners in its effort to reunite the formerly divided country. And like the DFG, the 5 per cent annual budget increase to which the society is committed until 1995 will be swallowed up by staff costs following the inflationary public sector wage settlement earlier this month (see Nature 357, 182; 1992).

The spirit of Germany may be willing, but it is becoming increasingly difficult to maintain the extraordinary speed and efficiency that has marked the first few years of reintegration of East German science.

Alison Abbott

\title{
Max Planck funds small projects
}

Munich. In the former DDR, research was mainly conducted in the 60 research units run by the National Academy of Science and concentrated around Berlin. Relatively little activity took place at universities, the traditional home for innovative research in West Germany.

But this situation is changing. The government's decision in June 1990 to harmonize research policy prompted the Max Planck Society, which normally sponsors only large-scale research that cannot be conducted within universities, to offer temporary support to de serving groups.

To protect research identified as very strong by evaluation committees of the society and the German Research Council (DFG), and to strengthen future university research, Max Planck is funding and administering 28 research groups in areas ranging from physics, to biochemistry to ecology. Funding will be restricted to five years. If the research develops well during this time, the universities will be expected to take over the financing directly.

The jewel in the eastern crown is Gunther Fischer's group from Halle. In the late 1980 s, Fischer was the first to identify and purify cis-trans peptidylprolyl isomerase, an enzyme which catalyses a rate-limiting step in protein folding. This enzyme was subsequently shown to be identical to cylcophilin, which binds the immunosuppressant drug cyclosporin, and it has helped to open up an important new field of biochemical immunology.

A special fund for these projects has been provided by the federal and regional governments, who normally split the costs of running the Max Planck Society. But the 1992 allocation of only DM130,000 (US $\$ 80,000$ ) per researcher, amounting to DM98,500 million in total, has been criticized as inadequate by Hans Zacher, president of Max Planck. Zacher would like to raise the average grant to DM180,000 in 1993.A.A.

\section{Researchers look beyond UNCED}

London. As diplomats, politicians and representatives from non-governmental organizations gather next week in Rio de Janeiro for the United Nations Conference on Environment and Development (UNCED), the environmental researchers whose work set the agenda for what is popularly known as the Earth Summit are concerned about what will happen afterwards.

"The critical period is what follows UNCED, and scientists are concerned about maintaining whatever momentum the conference has generated," said Jim Dooge, president-elect of the International Council of Scientific Unions (ICSU). "The key thing, post-UNCED, is science forging new partnerships with business, between the natural sciences and social sciences, and with policy makers."

Although some researchers bemoan the lack of scientific input into the conference itself, most recognize that Rio will be crowded enough over the next three weeks without them. The discussions that will take place will be largely political - UNCED is not now a scientific conference, if it ever was - and more than 100 heads of state are expected to address the delegates.

Although science may have been absent from the proceedings, environmental researchers have had an impact on the substantial issues being addressed. Bodies such as the Intergovernmental Panel on Climate Change and ICSU's ASCEND-21 meeting

\section{(An Agenda of Science for Environment} and Development into the 21st Century) have submitted weighty documents to the conference, as have individual scientific groups. Last week, for instance, the University of Oxford's Environmental Change Unit published a report entitled "Climate Change and World Food Supply". In addition, the efforts of researchers are represented in the various texts to be considered by UNCED delegates, and even if they are not adopted, it is hoped that their contribution will be recognized.

"Science has had a considerable input", says Tim O'Riordan, of the Centre for Social and Economic Research in the Global Environment, University of East Anglia, "but it is a matter of whether UNCED understands that, and if the documents produced from the conference reflect that. If that is not the case, then science will be damaged."

One way to bring that about is for Maurice Strong, secretary general of UNCED, to set up an office at the UN to set the agenda for future scientific work, including a roadmap that points out the gaps in existing knowledge and to areas that are most important. Although scientific programmes will undoubtedly continue in the wake of UNCED, researchers believe that the conference itself will heighten awareness of the issues and put pressure on governments to in crease their monitoring of environmental problems.

Ian Mundell 